\title{
Serum concentrations and renal expressions of IL-1 and TNF-a early after hemorrhage in rats under the effect of glibenclamide ${ }^{1}$
}

\author{
Christiane D'Oliveira Marques', Luis Antonio dos Santos Diego" ${ }^{\text {II }}$ Jussara Marcondes-Machado ${ }^{\text {III }}$, Renée Lauffer Amorim ${ }^{\text {IV }}$, \\ Lídia Raquel Carvalhov, Norma Sueli Pinheiro Módolo ${ }^{\mathrm{VI}}$, Leandro Gobbo Braz ${ }^{\mathrm{VII}}$, Yara Marcondes Machado Castiglia ${ }^{\mathrm{VIII}}$
}

\author{
DOI: http://dx.doi.org/10.1590/S0102-865020160070000002
}

${ }^{\mathrm{I}} \mathrm{MSc}$, Postgraduate Program in Anesthesiology, Botucatu Medical School, Universidade Estadual Paulista (UNESP), Botucatu-SP, Brazil. Conception, design, intellectual and scientific content of the study.

IPhD, Postgraduate Program in Anesthesiology, Botucatu Medical School, UNESP, Botucatu-SP, Brazil. Conception, design, intellectual and scientific content of the study.

IIIPhD, Department of Tropical Diseases, Botucatu Medical School, UNESP, Botucatu-SP, Brazil. Acquisition and interpretation of immunohistochemical data.

${ }^{\mathrm{IV}} \mathrm{PhD}$, Department of Pathology, Botucatu Veterinary and Animal Science School, UNESP, Botucatu-SP, Brazil. Acquisition of data, histological examinations.

vPhD, Department of Biostatistics, Bioscience Institute, UNESP, Botucatu-SP, Brazil. Acquisition of data, statistical analysis.

${ }^{\mathrm{VI} F u l l}$ Professor, Department of Anesthesiology, Botucatu Medical School, UNESP, Botucatu-SP, Brazil. Critical revision.

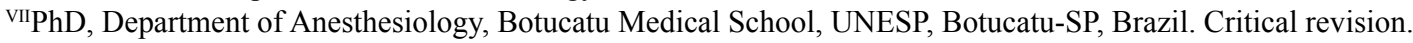

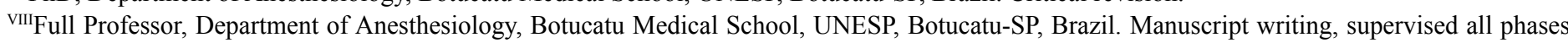
of the study.

\section{ABSTRACT}

PURPOSE: To investigate changes in the serum concentration and renal expression of IL-1 and TNF- $\alpha$ cytokines in rats that received sevoflurane and glibenclamide prior to hemorrhage.

METHODS: Two groups of sevoflurane-anesthetized Wistar rats (n=10): G1 (control) and G2 (glibenclamide, $1 \mu \mathrm{g} / \mathrm{g}$ i.v.); hemorrhage of $30 \%$ blood volume ( $10 \%$ every $10 \mathrm{~min}$ ), with replacement using Ringer solution, $5 \mathrm{ml} / \mathrm{kg} / \mathrm{h}$. Serum concentrations of IL-1 and TNF- $\alpha$ were studied in the first hemorrhage (T1) and 50 min later (T2), renal expression, at $\mathrm{T} 2$.

RESULTS: In serum, G1 TNF- $\alpha(\mathrm{pg} / \mathrm{mL})$ was $\mathrm{T} 1=178.6 \pm 33.5, \mathrm{~T} 2=509.2 \pm 118.8(\mathrm{p}<0.05) ; \mathrm{IL}-1(\mathrm{pg} / \mathrm{mL})$ was $\mathrm{T} 1=148.8 \pm 31.3$, $\mathrm{T} 2=322.6 \pm 115.4(\mathrm{p}<0.05)$; in $\mathrm{G} 2, \mathrm{TNF}-\alpha$ was $\mathrm{T} 1=486.2 \pm 83.6, \mathrm{~T} 2=261.8 \pm 79.5(\mathrm{p}<0.05)$; IL- 1 was $\mathrm{T} 1=347.0 \pm 72.0, \mathrm{~T} 2=327.3 \pm 90.9$ $(p>0.05$ ). The expression of TNF- $\alpha$ and IL-1 in the glomerular and tubular cells was significantly higher in the G2 group.

CONCLUSIONS: Hemorrhage and glibenclamide elevated TNF- $\alpha$ and IL-1 concentrations in serum and kidneys. High levels of TNF- $\alpha$ already present before the hemorrhage in the glibenclamide group may have attenuated the damages found in the kidneys after the ischemia event.

Key words: Hemorrhage. Glyburide. Cytokines. Kidney. Rats. 


\section{Introduction}

Hemorrhagic shock produces multiple abnormalities in immunological functions, resulting in immunodeficiency and a subsequent increased susceptibility to sepsis ${ }^{1}$. Tissue hypoxia that occurs after hemorrhagic shock produces changes in cellular organic metabolism ${ }^{2}$, and induces the release of proinflammatory cytokines, such as interleukins one and six (IL-1 and IL-6) and tumor necrosis $\alpha$ factor (TNF- $\alpha$ ), into the plasma. The excessive activation of inflammatory mediators after trauma/hemorrhagic shock leads to multiple organ dysfunction syndromes, a major cause of mortality in patients $\mathrm{s}^{3-5}$. Ischemia/reperfusion process triggers macrophages and activated Küpffer cells release inflammatory cytokines ${ }^{6}$. Glibenclamide, an anti-diabetic agent, is a $\mathrm{K}_{\text {ATP }}$ channel antagonist with half-life of $4 \pm 1$ hour $^{7-9}$. Some experimental studies have shown a possible relationship between glibenclamide action on the $\mathrm{K}_{\text {ATP }}$ channel and effects in the inflammatory process ${ }^{10,11}$. A previous study from our laboratory has investigated the action of glibenclamide in the kidneys of rats anesthetized with sevoflurane that suffered $30 \%$ blood volume loss and hemorrhagic shock secondary to inadequate fluid replacement. Animals treated with glibenclamide showed better renal function and histology, i.e., greater renal effective plasma flow, no changes in glomerular filtration rate, lower renal vascular resistance and less necrosis than the control group ${ }^{12}$. This experimental model has clinical equivalence in cases of patients under glibenclamide regimen who underwent surgical treatment of the consequences of trauma followed by hemorrhagic shock, a very common and current medical emergency, mainly related to urban violence. The positive results of Diego et al. ${ }^{12}$ encouraged us to investigate, in an identical experimental model, if glibenclamide and sevoflurane has some relation with the production of the proinflammatory cytokines TNF- $\alpha$ and IL-1 in serum and kidney tissue of rats after induced hemorrhagic shock.

\section{Methods}

Ethics Committee in Animal Experimentation of the Botucatu Medical School, UNESP, approved the study that involved 20 adult Wistar rats, randomly distributed into two groups of 10 rats each, G1 and G2; all rats were anesthetized with sevoflurane and subjected to $30 \%$ blood volume loss. The rats in $\mathrm{G} 2$ received glibenclamide intravenously. The animals were housed in a transparent bell made of inert material and injected with $4 \%$ sevoflurane with a total flow of $1 \mathrm{~L} / \mathrm{min}$ of $\mathrm{O}_{2}$ and $1 \mathrm{~L} /$ min of air from an Ohmeda vaporizer (USA). After the induction of anesthesia, the anesthetic concentration was decreased to $2.5 \%$, and an appropriate mask non-rebreathing system was used; the rat maintained spontaneous breathing in the oxygen/air/sevoflurane mixture. The rectal temperature $(\mathrm{T})$ was monitored and maintained between $35.5^{\circ} \mathrm{C}$ and $37.5^{\circ} \mathrm{C}$ with a compressor-heater system.

The right internal jugular vein was dissected and cannulated with a $24 \mathrm{GA}$ venocath; rats received $5 \mathrm{~mL} / \mathrm{kg} / \mathrm{h}$ of a lactated Ringer solution for replacement of negligible losses ${ }^{12,13}$. Immediately after the catheterization, G2 received intravenous glibenclamide (Glyburide ${ }^{\hat{a}}-$ Sygma, $0.1 \%$ ), $1 \mu \mathrm{g} / \mathrm{g}$. The left carotid artery was dissected and cannulated with a 24 GA venocath to monitor the mean arterial pressure (MAP) using the Datex Engstron recording device (Finland).

Sixty minutes after glibenclamide administration in G2 and the corresponding time in G1, the animals from both groups underwent $30 \%$ blood volume loss through the carotid artery, which was performed in three time points with ten minutes of interval. At each time point, $10 \%$ of the total blood volume was withdrawn. Total blood volume was calculated as $6 \%$ of the body weight $^{14}$. The arterial blood collected was used for laboratory analysis serum TNF- $\alpha$ and IL- 1 cytokines.

After the last hemorrhage time point, the rats remained anesthetized for another 30 minutes, a bilateral nephrectomy was conducted, and the animals were euthanized with appropriate dose of sodium pentobarbital. Both kidneys removed were immediately sectioned along the longest axis and stored for immunohistochemical analysis in a Dubosque-Brazil solution (120 $\mathrm{mL}$ formaldehyde, $30 \mathrm{~mL}$ acetic acid and $2 \mathrm{~g}$ picric acid), for a minimum of 12 hours and a maximum of 36 hours; they were then transferred to $70 \%$ ethanol. Finally, coded numbers identified the kidneys.

In order to perform histologic study, slices with fragments from both kidneys were prepared by fixing in paraffin and then staining with hematoxylin/eosin (HE). Histology was evaluated and based on the following criteria: tubular dilation and necrosis. Tubular necrosis was diagnosed by identifying nuclear necrosis and cytoplasmatic debris. Intensity scores were attributed to lesions, in increasing order of intensity: zero (0) absence of lesion; one (1) discreet lesions; two (2) moderate lesions; and three (3) intense lesions.

The studied attributes were, as follows: serum concentrations of TNF- $\alpha$ and IL-1 and renal tubular and glomerular TNF- $\alpha$ and IL-1 immunostaining. The serum concentrations were studied in time points $\mathrm{T} 1$, which was the control and coincident with the first hemorrhage, and T2, which occurred 30 minutes from the third and last hemorrhage and immediately before the 
euthanasia of each animal.

TNF- $\alpha$ and IL- 1 were determined in serum by ELISA kit (R\&D Systems, Minneapolis, USA) and in renal tubules and glomeruli by immunohistochemical reactions. Normal serum levels were considered as the mean values found in serum of five healthy rats using the same methodology (ELISA, R\&D Systems, Minneapolis, U.S.A.) plus one standard deviation: TNF- $\alpha=117$ $\mathrm{pg} / \mathrm{mL} \pm 26$, or, totaling one standard deviation, $\mathrm{TNF}-\mathrm{a}=143 \mathrm{pg} /$ $\mathrm{mL}$; IL-1 $=121 \mathrm{pg} / \mathrm{mL} \pm 37$, or, totaling one standard deviation IL-1 $=158 \mathrm{pg} / \mathrm{mL}$.

\section{Statistical analysis}

The analysis of percentage and intensity of cytokine staining frequencies in the glomerular and tubular cells were made by Goodman test and the distribution of percentage and intensity of IL-1 frequencies in the glomerular cells by Fisher exact test. The Profile analysis of serum cytokines levels over time (T1 and T2) was conducted with tests to determine: 1) interaction between groups and time points, to verify similarity throughout the periods between both groups; 2) parity between both groups at all time points (the difference between both profiles) in the case of similarity acceptance; 3 ) the difference between time points in all the groups in the case of similarity acceptance; 4) the difference between groups at each time point; 5) the difference between time points within each group. $F$ and $p$ statistics were calculated in each tested hypothesis. Histological scores (0-3) in each kidney and comparison between the two groups were analyzed by the non-parametric Mann-Whitney test for independent groups. The differences were considered significant for $p$-values $<0.05$.

\section{Results}

The animal weights $(\mathrm{g})$ did not differ between $\mathrm{Gl}$ and G2, and were, respectively, $346 \pm 81$ and $338 \pm 62$. In G1, initial (T1) serum levels of TNF- $\alpha(\mathrm{pg} / \mathrm{mL})$ were higher than normal $(178.6 \pm 33.5)$. Fifty minutes later (T2), these values had increased to $509.2 \pm 118.8(\mathrm{p}<0.05)$; in G2, TNF- $\alpha$ serum levels were 486.2 \pm 83.6 (T1) decreasing to $261.8 \pm 79.5(\mathrm{~T} 2)(\mathrm{p}<0.05)$ (Table 1). In $\mathrm{T} 1, \mathrm{G} 1<\mathrm{G} 2$, and in $\mathrm{T} 2, \mathrm{G} 1>\mathrm{G} 2(\mathrm{p}<0.05)$. Initial serum levels of IL-1 (pg/mL) (T1) in G1 were discretely lower than normal (148.8 $\pm 31.3)$, but increased significantly in $\mathrm{T} 2(322.6 \pm 115.4)(\mathrm{p}<0.05)$. In G2, serum levels of IL-1 were $347.0 \pm 72.0$, in T1 and decreased to $327.3 \pm 90.9$, in $\mathrm{T} 2$ (Table 1$)$. In $\mathrm{T} 1, \mathrm{G} 1<\mathrm{G} 2(\mathrm{p}<0.05)$.

TABLE 1 - Mean \pm standard deviation of TNF- $\alpha$ and IL-1 serum cytokine (pg/mL) levels, according to time points (T1 and T2) and groups (G1 and G2, each one with 10 rats submitted to hemorrhage of 30\% of total blood volume, and G2 also to glibenclamide).

\begin{tabular}{ccccc}
\hline & \multicolumn{2}{c}{ TNF- $\boldsymbol{\alpha}$ serum } & \multicolumn{2}{c}{ IL-1 serum } \\
Groups & T1 & T2 & T1 & T2 \\
\hline G1 & $178.6 \pm 33.5^{*} \#$ & $509.2 \pm 118.8^{*} \#$ & $148.8 \pm 31.3^{*} \#$ & $322.6 \pm 115.4^{*}$ \\
G2 & $486.2 \pm 83.6^{* \#}$ & $261.8 \pm 79.5^{*} \#$ & $347.0 \pm 72.0 \#$ & $327.3 \pm 90.9 \mathrm{a}$ \\
\hline
\end{tabular}

Profile analysis $\mathrm{p}<0.05 *$ difference between T1 and T2; \# difference between G1 and G2; T1 = time point control and coincident with the first hemorrhage period $(10 \%$ of total blood volume); $\mathrm{T} 2=$ time point which occurred $30 \mathrm{~min}$ from the third and last hemorrhage period $(10 \%$ of total blood volume $)$ and immediately before the euthanasia of each animal.

Renal expression of TNF- $\alpha$ in tubular cells (Table 2, Figure 1) showed 12 kidneys in G1 with staining percentages of up to $25 \%(\mathrm{p}=0.03)$. In $\mathrm{G} 2,7 / 20$ kidneys presented staining percentages from $76 \%$ to $100 \%(\mathrm{p}=0.03)$, a result that was significant comparing to the remaining 13 . There was no significant difference between renal expressions of TNF- $\alpha$ in tubular cells of both groups.
TABLE 2 - Distribution of kidneys from rats of G1 and $\mathrm{G} 2$ groups (10 rats and 20 kidneys each), both submitted to hemorrhage of $30 \%$ of total blood volume, and $\mathrm{G} 2$ also to glibenclamide, according to the percentage of tubular cell staining for TNF- $\alpha$ and IL-1.

\begin{tabular}{ccccc}
\hline & \multicolumn{2}{c}{ TNF- $\alpha$} & \multicolumn{2}{c}{ IL-1 } \\
\hline $\begin{array}{c}\text { Staining } \\
\text { Intensity }\end{array}$ & $\begin{array}{c}\text { Number } \\
\text { of } \\
\text { kidneys }\end{array}$ & $\begin{array}{c}\text { Number } \\
\text { of } \\
\text { kidneys }\end{array}$ & $\begin{array}{c}\text { Number } \\
\text { of } \\
\text { kidneys }\end{array}$ & $\begin{array}{c}\text { Number } \\
\text { of } \\
\text { kidneys }\end{array}$ \\
\hline Without & 2 & Zero & $6 \#$ & zero \\
Staining & 2 & 5 & $5 \#$ & $5 \#$ \\
Up to $25 \%$ & $12 \#$ & 2 & $4 \#$ & 2 \\
26 to $50 \%$ & 2 & 6 & $5 \#$ & $6 \#$ \\
51 to $75 \%$ & 3 & $7 \#$ & zero & $7 \#$ \\
76 to $100 \%$ & 1 & &
\end{tabular}




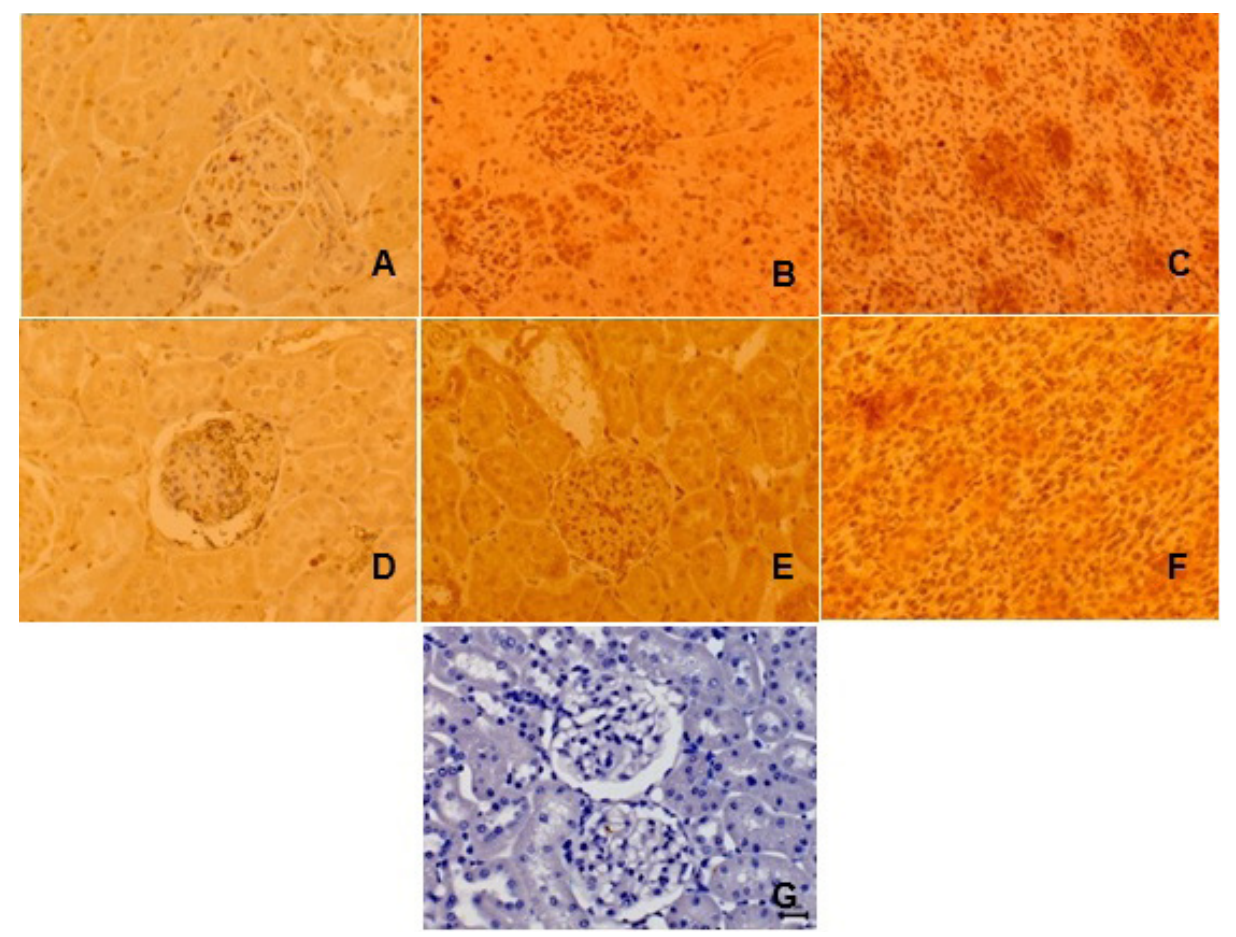

FIGURE 1 - Immunostaining (I) of tissue from rat kidneys following hemorrhage of 30\% of total blood volume. Primary antibody antilL-1 and antiTNF- $\alpha$ technique: ABCDEF, DAB and counterstained with Harris hematoxylin, x400: A - IL-1 weak I, in renal glomerulus and tubuli of rat from G1 group (sevoflurane); B - IL-1 strong I, in renal glomeruli of rat from G2 group (sevoflurane plus glibenclamide); C - IL-1 strong I, in renal tubuli of rat from G2 group; D - TNF-a weak I, in renal glomerulus and tubuli of rat from G2 group; E - TNF-a strong I, in renal glomerulus of rat from G2 group; F - TNF-a strong I, in renal tubuli of rat from G2 group; $\mathbf{G}$ - negative control.

TNF- $\alpha$ glomerular cells expression in ten kidneys of G1 (Table 3, Figure 1) presented staining percentages of up to $25 \%$ $(\mathrm{p}=0.01)$, in $\mathrm{G} 2,10 / 20$ kidneys presented staining percentages between $76 \%$ and $100 \%(\mathrm{p}=0.01)$. The comparison between the groups showed that, in G1, there were more kidneys with staining percentages of up to $25 \%$; G2 had a higher number of kidneys in the staining percentages from $76 \%-100 \%$. These differences were significant.

TABLE 3 - Distribution of kidneys from rats of G1 and G2 groups (10 rats and 20 kidneys each), both submitted to hemorrhage of $30 \%$ of total blood volume, and G2 also to glibenclamide, according to the percentage of glomerular cells staining for TNF- $\alpha$ and IL-1.

\begin{tabular}{|c|c|c|c|c|}
\hline \multirow[b]{2}{*}{$\begin{array}{l}\text { Staining } \\
\text { Intensity }\end{array}$} & \multicolumn{2}{|c|}{ TNF- $\alpha$} & \multicolumn{2}{|c|}{ IL-1 } \\
\hline & $\begin{array}{c}\text { G1 } \\
\text { Number } \\
\text { of } \\
\text { kidneys }\end{array}$ & $\begin{array}{c}\text { G2 } \\
\text { Number } \\
\text { of } \\
\text { kidneys }\end{array}$ & $\begin{array}{c}\text { G1 } \\
\text { Number } \\
\text { of } \\
\text { kidneys }\end{array}$ & $\begin{array}{c}\text { G2 } \\
\text { Number } \\
\text { of } \\
\text { kidneys }\end{array}$ \\
\hline $\begin{array}{l}\text { Without } \\
\text { Staining }\end{array}$ & 2 & zero & 3 & zero \\
\hline Up to $25 \%$ & $10 \#$ & 5 & 6 & 4 \\
\hline 26 to $50 \%$ & 2 & 1 & 3 & 3 \\
\hline 51 to $75 \%$ & 5 & 4 & 2 & 9 \\
\hline 76 to $100 \%$ & 1 & $10 \#$ & 6 & 4 \\
\hline
\end{tabular}

\# among $\%$ of staining inside the group: $\mathrm{p}=0.01$ for TNF- $\alpha$, Goodman test; $\mathrm{p}=$ 0.08 for IL-1, Fisher exact test
Renal tubular cells expression of IL-1 (Table 2, Figure 1 ), in G1, was not present in six kidneys while five presented staining of up to $25 \%$, four staining from $26 \%$ to $50 \%$ and five organs presented staining from $51 \%$ to $75 \%$, but these differences were not significant. No kidney staining from $76 \%$ to $100 \%$ was observed in this group. In G2, seven kidneys, out of the total 20 , presented staining from $76 \%$ to $100 \%$, six from $51 \%$ to $75 \%$, and five of up to $25 \%$. Although no significance was found in the different intensities of the stainings observed, these were greater than the staining from $26 \%$ to $50 \%$ that was found in the two remaining kidneys of G2. No kidney was found without staining $(p=0.03)$ in this group. Renal expression of IL-1 in both groups differed significantly: in G1, six kidneys had no staining, whereas in G2 no organ presented this result; in G2, seven kidneys had $76 \%$ to $100 \%$ of staining, while no kidney from G1 presented such level.

The study of IL-1 expression in the glomerular cells of G1 (Table 3, Figure 1) showed three kidneys without staining, six kidneys with staining up to $25 \%$, three with staining from $26 \%$ to $50 \%$, while two kidneys had staining from $51 \%$ to $75 \%$ and six from $76 \%$ to $100 \%$. Also, there was no significant difference among the four kidneys, out of the total 20 , of G2, which presented staining from $76 \%$ to $100 \%$ and the nine with staining from $51 \%$ to $75 \%$, the three from $26 \%$ to $50 \%$ and the four with up to $25 \%$ 
staining. There was no significant difference between G1 and G2 in the IL-1 expressions found in the glomerular cells $(\mathrm{p}=0.08)$.

Tubular dilation and necrosis were observed in the renal cortical area 30 minutes after the hemorrhage of $30 \%$ of total blood volume in both G1 and G2 rats. All the animals of G1 presented tubular dilation that was discrete in two animals, moderate in seven and intense in one. In G2, tubular dilation was not seen in two animals and was discrete in eight ( $\mathrm{G} 1>\mathrm{G} 2 ; \mathrm{p}<0.05)$. Tubular necrosis was seen in animals of both G1 and G2. In G1, it was discrete in three, moderate in three, intense in two and it was absent in two. In G2, it was absent in six, discrete in one, moderate in two and intense in one (Figure 2).

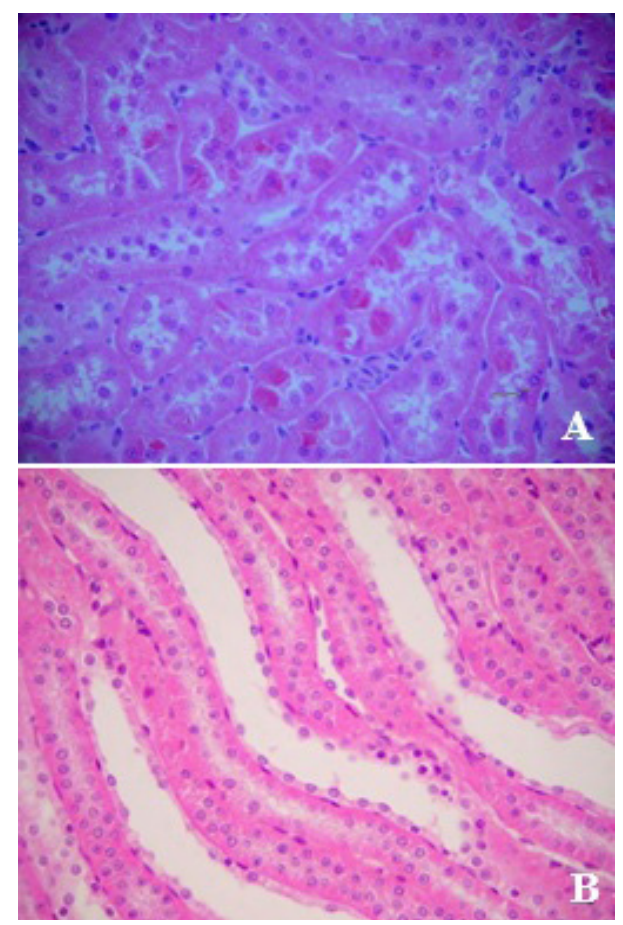

FIGURE 2 - A) Necrosis of tubules and B) dilated tubules in the renal cortex of rats anesthetized with sevoflurane and submitted to hemorrhage of $30 \%$ of volemia (G1 group). HE-x 40 .

\section{Discussion}

In many organs, ischemia/reperfusion period is associated with acute inflammation and release of proinflammatory cytokines, but the exact mediating role of these substances on organ injury is unclear ${ }^{15,16}$. Multiple trauma and ischemia/reperfusion injuries are situations that initiate cytokine cascade and result in local and systemic inflammatory processes. Biologically, IL-1 and TNF- $\alpha$ are closely correlated, even though their structures and receptors are distinct ${ }^{17}$. The kidney is capable of producing TNF- $\alpha$ in response to lipopolysaccharide, through its own TNF- $\alpha$ up-regulation mechanism or IL-1. The oxidants released during reperfusion of an ischemic tissue stimulate transcription factors involved in TNF- $\alpha$ expression ${ }^{18}$. When large quantities of TNF- $\alpha$ are produced, myocardial contractility and the smooth muscle tone of vessels are inhibited, resulting in vasodilatation and an acute drop in blood pressure or shock ${ }^{19}$.

In this study, the ischemia that occurred in the kidney was likely due to hemorrhaging without total loss of blood flow. Organ reperfusion occurred either through the external replacement of fluids that was provided or through an intrinsic self-preserving mechanism of the organ.

Sevoflurane inhibits the production of TNF- $\alpha^{20,21}$, resulting in protection against myocardial ischemia and reperfusion injury ${ }^{22}$. According to Kawamura et al. ${ }^{23}$, the balance between pro and antiinflammatory cytokine production may be one of the most important protective mechanisms determined by sevoflurane on myocardium. Renal protection by sevoflurane is still controversial, mainly because of the lack of uniformity in the research models used in the different studies ${ }^{24,25}$.

In our study, TNF- $\alpha$ serum levels were already elevated in T1. Surgical stress for establishing the research model may have led to the slight elevation of cytokine levels found in G1, and the addition of glibenclamide, to the significant elevation in G2. The hemorrhage caused in the animals at T2 may have stimulated TNF- $\alpha$ release, for the levels of this cytokine appear very elevated in G1. In G2, the increased TNF- $\alpha$ levels in T2 were less important than in $\mathrm{T} 1$ and also lower than in G1, although the concentration of the cytokine was twice the normal values. Inhibition of TNF- $\alpha$ production seen in T2 may have occurred in G2 as a preventive mechanism of overall inflammation, since TNF- $\alpha$ receptors are found in practically all organ cells. It is known that TNF- $\alpha$ induces the formation of soluble receptors in blood circulation ${ }^{26-28}$, which may act as natural inhibitors of that cytokine. If this is true, this same protective mechanism was to be seen later in $\mathrm{G} 1$, had the time of observation been longer, because the important elevation of TNF- $\alpha$ levels had only occurred between T1 and T2 in this group.

Renal TNF- $\alpha$ immunoexpression was more homogenous in $\mathrm{G} 2$ because all the cells were stained, and many large areas with very strong staining were seen. On the contrary, the distribution of TNF- $\alpha$ staining in G1 was not homogenous, and the largest part of the kidneys showed weak staining, with unstained areas being observed. Glibenclamide, in addition to inducing TNF- $\alpha$ serum formation, also induces the expression of TNF- $\alpha$ renal receptors. Therefore, in G2, all the TNF- $\alpha$ produced was taken by tubular and glomerular receptors. It is worth mentioning that glibenclamide 
behaved as a proinflammatory agent, playing a supporting role to TNF- $\alpha$. However, a study in rats observed that glibenclamide reduced Central Nervous System (CNS) inflammation after subarachnoid hemorrhage, which indicates a positive action of this drug against the proinflammatory effects of cytokines, such as TNF- $\alpha^{29}$.

In patients with type-2 diabetes mellitus, glibenclamide administration inhibits increased monocyte adhesion to endothelial cells, thus decreasing TNF- $\alpha$ production by these cells ${ }^{30}$. In mice, glibenclamide did not have an effect on the production of TNF- $\alpha$ and had very little effect on the activity of this cytokine, according to Fukuzawa et al..$^{31}$. Jiang et al. ${ }^{32}$ found TNF- $\alpha$ as the first cytokine to appear after hemorrhage shock in rat tissue, followed by IL-1 $\beta$.

A study on the role of TNF- $\alpha$ in renal dysfunction of rats that suffered $16.5 \%$ blood volume loss, without fluid resuscitation, used a compound that antagonized an intracellular signaling pathway that was important for mRNA expression of proinflammatory cytokines, such as TNF- $\alpha$ and IL-1 $\beta$. One hour after hemorrhage, TNF- $\alpha$ mRNA expression in the kidney, as well as the serum concentrations of the cytokine, were elevated in non-treated animals, but prior intraperitoneal treatment with the compound significantly inhibited TNF- $\alpha$ elevation. The infiltration of inflammatory cells and tubular cell injury, induced by hemorrhage, was suppressed, and renal dysfunction was dramatically reduced in the group that received treatment with this compound. Morphological changes were also milder in the treated group when compared with the non-treated group ${ }^{33}$. Glibenclamide also ameliorated several pathological effects associated with inflammation in CNS by blocking sulfonylurea receptor 1 (SUR1) ${ }^{29}$. Another protective mecanism advocated for glibenclamide against renal injury caused by ischemia/reperfusion is that of blocking $\mathrm{K}_{\text {ATP }}$ channel $^{11}$. This sulfonylurea also has direct antioxidant potential with significant elevation of antioxidant enzyme activity and reduction in lipid peroxidation ${ }^{34}$. This is an interesting objective for future research using the present experimental model.

Serum IL-1 levels of G1 animals, that were normal before the beginning of the bleeding, had reached twice the normal values by the end of the experiment, probably induced by hemorrhage. In G2, IL-1 values were already very high in T1, possibly as a result of glibenclamide stimulation and remained elevated until the end of the experiment, likely due to the three bleeding events. Thus, equal values of IL-1 in T2 of both G1 and G2 probably reflect the stimulating effect of glibenclamide and hemorrhage on the production of this cytokine.
In the glomerular cells, a significant difference in IL-1 staining was not observed between the groups; all of the cells were stained, and the majority of kidneys studied had very strong staining. In tubular cells, IL-1 staining was greater in G2; all of the studied cells were stained as were the majority of the kidneys, which also had very strong staining.

There are soluble IL-1 receptors that also inhibit the action of this cytokine in a dose-dependent manner. However, immunomodulation through IL-1 receptors seems to be less important than those of TNF- $\alpha$ receptors, since the latest are found in a greater number of organ cells. The general effects of IL-1 are the same of TNF- $\alpha$, although it does not cause tissue damage by itself and is not lethal, even in high concentrations ${ }^{28}$.

IL-1 and TNF- $\alpha$ action was found to be synergic in almost all the in vitro and in vivo models of local or systemic inflammation. When either of the cytokines is specifically blocked, the severity of inflammation decreases ${ }^{28}$. In this study, hemorrhage and glibenclamide were shown to induce elevations of IL-1 and TNF- $\alpha$ levels, both in rat serum and kidneys, and sevoflurane was a factor that may have reduced this increase. TNF- $\alpha$ is a cytokine that promotes vasodilatation and was already presented in high concentration, in T1, in the animals of G2. These animals had better perfusion and milder ischemia, because of hypotension. Otherwise, in G1, renal changes would have been worse had the rats not received sevoflurane.

The histologic injuries seen in both groups - tubular dilation and necrosis - may be attributed to low perfusion conditions after hemorrhagic shock, according to Guedes et al. ${ }^{35}$, in a similar experimental model. Depending on the degree of the hypotensive insult, the kidney would manifest acute spasm of the preglomerular arterioles with acute tubular necrosis ${ }^{36}$. In our study, the two types of histologic injuries occurred in both groups, but were more intense in G1. These findings may suggest a protective role of glibenclamide against renal aggression, through vasodilatation induction resulting in a better tissue perfusion.

Further studies are needed to demonstrate if glibenclamide does have a protective role against immunemodulated renal aggression.

\section{Conclusions}

Hemorrhage and glibenclamide elevated TNF- $\alpha$ and IL-1 concentrations in serum and kidneys. High levels of TNF- $\alpha$ already present before the hemorrhage in the glibenclamide group may have attenuated the damages found in the kidneys after the ischemia event. 


\section{References}

1. Chaudry IH, Ayala A, Ertel W, Stephan RN. Hemorrhage and resuscitation: immunological aspects. Am J Physiol. 1990 Oct;28(4 Pt 2):R663-78. PMID: 2145776.

2. Chaudry IH, Sayeed MM, Baue AE. Differences in the altered energy metabolism of hemorrhagic shock and hypoxemia. Can J Physiol Phamacol. 1976 Oct;54(5):750-6. PMID: 11040.

3. Roumen RM, Hendriks T, van der Ven-Jongekrijg J, Nieuwenhuijzen GA, Sauerwein RW, van der Meer JW, Goris RJ. Cytokine patterns in patients after major vascular surgery, hemorrhagic shock, and severe blunt trauma. Relation with subsequent adult respiratory distress syndrome and multiple organ failure. Ann Surg. 1993 Dec;218(6):769-76. PMID: 8257227.

4. Bahrami S, Yao YM, Leichtfried G, Redl H, Marzi I, Schlag G. Significance of TNF in hemorrhage-related hemodynamic alterations, organ injury, and mortality in rats. Am J Physiol. 1997 May;272(5 Pt 2):H2219-26. PMID: 9176289.

5. Yao Y-M, Redl H, Bahrami S, Schlag G. The inflammatory basis of trauma/shock- associated multiple organ failure. Inflamm Res. 1998 May;47(5):201-10. PMID: 9657252.

6. Mauriz JL, Martín Renedo J, Barrio JP, Culebras JM, González P. Experimental models on hemorrhagic shock. Nutr Hosp. 2007 MarApr;22(2):190-8. PMID: 17416035.

7. Aguilar-Bryan L, Nichols CG, Wechsler SW, Clement JP 4th, Boyd AE 3rd, González G, Herrera-Sosa H, Nguy K, Bryan J, Nelson DA. Cloning of the beta cell high-affinity sulfonylurea receptor: a regulator of insulin secretion. Science. 1995 Apr 21;268(5209):4236. PMID: 7716547.

8. Philipson LH, Steiner DF. Pas de deux or more: the sulfonylurea receptor and K+ channels. Science. 1995 Apr 21;268(5209):372-3. PMID: 7716539.

9. Cleveland JC Jr, Meldrum DR, Cain BS, Banerjee A, Harken AH. Oral sulfonylurea hypoglycemic agents prevent ischemic preconditioning in human myocardium. Two paradoxes revisited. Circulation. 1997 Jul;96(1):29-32. PMID: 10534420.

10. da Silva-Santos JE, Santos-Silva MA, Cunha FQ, Assreuy J. The role of ATP-sensitive potassium channels in neutrophil migration and plasma exudation. J Pharmacol Exp Ther. 2002 Mar;300(3):94651. PMID: 11861802.

11. Pompermayer K, Souza DG, Lara GG, Silveira KD, Cassali GD, Andrade AA, Bonjardim CA, Passaglio KT, Assreuy J, Cunha FQ, Vieira MA, Teixeira MM. The ATP-sensitive potassium channel blocker glibenclamide prevents renal ischemia/reperfusion injury in rats. Kidney Int. 2005 May;67(5):1785-96. PMID: 15840025.

12. Diego LAS, Marques CD'O, Vianna PTG, Viero RM, Braz JR, Castiglia YMM. Glibenclamide effects on renal function and hystology after acute hemorrhage in rats under sevoflurane anesthesia. Ren Fail. 2007;29(8):1039-45. PMID: 18067053.

13. de Souza Silva M, Castiglia YMM, Vianna PTG, Viero RM, Braz JR, Cassetari ML. Rat model of depending prostaglandin renal state: effect of ketoprofen. Ren Fail. 2006;28(1):77-84. PMID: 16526323.

14. Erni D, Banic A, Wheatley AM, Sigurdssonn GH. Haemorrhage during anaesthesia and surgery: continuous measurement of microcirculatory blood flow in the kidney, liver, skin and skeletal muscle. Eur J Anaesthesiol. 1995 Jul;12(4):423-9. PMID: 7588673.

15. Frangogiannis NG, Youker KA, Rossen RD, Gwechenberger M, Lindsey MH, Mendoza LH, Michael LH, Ballantyne CM, Smith $\mathrm{CW}$, Entman ML. Cytokines and the microcirculation in ischemia and reperfusion. J Mol Cell Cardiol. 1998 Dec;30(12):2567-76. PMID: 9990529.

16. Hill GE. Cardiopulmonary bypass-induced inflammation: Is this important? J Cardiothorac Vasc Anesth. 1998 Apr;12(2 Suppl 1):215. PMID: 9583572.
17. Dinarello CA. Proinflammatory and anti-inflammatory cytokines as mediators in the pathogenesis of septic shock. Chest. 1997 Dec;112(6 Suppl):321S-9. PMID: 9400897.

18. Donnahoo KK, Meng X, Ayala A, Cain MP, Harken AH, Meldrum DR. Early kidney TNF- $\alpha$ expression mediates neutrophil infiltration and injury after renal ischemia-reperfusion. Am J Physiol. 1999 Sep;277(3 Pt 2):R922-9. PMID: 10484513.

19. Abbas AK, Lichtman AH, Pillai S. Cellular and Molecular Immunology. 6ed. Philadelphia: Saunders; 2007.

20. El Azab SR, Rosseel PM, De Lange JJ, Groeneveld AB, Van Strik R, Van Wijk EM, Scheffer GJ. Effect of sevoflurane on the ex vivo secretion of TNF-alpha during and after coronary artery bypass surgery. Eur J Anaesthesiol. 2003 May;20(5):380-4. PMID: 12790209.

21. Nader ND, Li CM, Khadra WZ, Reedy R, Panos AL. Anesthetic myocardial protection with sevoflurane. J Cardiothorac Vasc Anesth. 2004 Jun;18(3):269-74. PMID: 15232804.

22. Kowalski C, Zahler S, Becker BF, Flaucher A, Conzen PF, Gerlach E, Peter K.. Halothane, isoflurane, and sevoflurane reduce postischemic adhesion of neutrophils in the coronary system. Anesthesiology. 1997 Jan;86(1):188-95. PMID: 9009954.

23. Kawamura T, Kadosaki M, Nara N, Kaise A, Suzuki H, Endo S, Wei J, Inada K. Effects of sevoflurane on cytokine balance in patients undergoing coronay artery bypass graft surgery. J Cardiothorac Vasc Anesth. 2006 Aug;20(4):503-8. PMID: 16884979.

24. Obal D, Dettwiler S, Favoccia C, Rascher K, Preckel B, Schlack $\mathrm{W}$. Effect of sevoflurane preconditioning on ischaemia/reperfusion injury in the rat kidney in vivo. Eur J Anaesthesiol. 2006 Apr;23(4):319-26. PMID: 16469207.

25. Lee HT, Chen SWC, Doetschman TC, Deng C, D'Agati VD, Kim $M$. Sevoflurane protects against renal ischemia and reperfusion injury in mice via the transforming growth factor- $\beta 1$ pathway. Am J Physiol Renal Physiol. 2008 Jul;295(1):F128-36. doi: 10.1152/ ajprenal.00577.2007.

26. Engelmann H, Holtmann H, Brakebusch C, Avni YS, Sarov I, Nophar Y, Hadas E, Leitner O, Wallach D. Antibodies to a soluble form of a tumor necrosis factor (TNF) receptor have TNF-like activity. J Biol Chem. 1990 Aug 25;265(24):14497-504. PMID: 1696947.

27. Jansen J, van der Poll T, Levi M, ten Cate H, Gallati H, ten Cate JW, van Deventer SJ. Inhibition of the release of soluble tumor necrosis factor receptors in experimental endotoxemia by anti-tumor necrosis factor antibody. J Clin Immunol. 1995 Jan;15(1):45-50. PMID: 7759600.

28. Dinarello CA. Cytokines as mediators in the pathogenesis of septic shock. Curr Top Microbiol Immunol. 1996;216:133-65. Review. PMID: 8791739.

29. Simard JM, Geng Z, Woo SK, Ivanova S, Tosun C, Melnichenko L, Gerzanich V. Glibenclamide reduces inflammation, vasogenic edema, and caspase-3 activation after subarachnoid hemorrhage. J Cereb Blood Flow Metab. 2009 Feb;29(2):317-30. doi: 10.1038/ jcbfm.2008.120.

30. Desfaits A-C, Serri O, Renier G. Normalization of plasma lipid peroxides, monocyte adhesion, and tumor necrosis factor- $\alpha$ production in NIDDM patients after glicazide treatment. Diabetes Care. 1998 Apr;21(4):487-93. PMID: 9571329.

31. Fukuzawa M, Satoh J, Qiang X, Miyaguchi S, Sakata Y, Nakazawa $\mathrm{T}$, Ikehata $\mathrm{F}$, Ohta $\mathrm{S}$, Toyota $\mathrm{T}$. Inhibition of tumor necrosis factor- $\alpha$ with anti-diabetic agents. Diabetes Res Clin Pract. 1999 Mar;43(3):147-54. PMID: 10369423.

32. Jiang J, Tian K, Diao Y, Chen H, Zhu P, Wang Z. Expression of TNF alpha, IL-1 beta, IL-6 mRNA, release of TNF-alpha in vital organs and their relationship with endotoxin translocation following hemorrhagic shock. Chin Med Sci J. 1997 Mar;12(1):41-6. PMID: 11243098 . 
33. Sato H, Tanaka T, Kita T, Yamaguchi H, Tanaka N. The role of tumour necrosis factor- $\alpha$ in renal dysfunction following mild haemorrhage in rats. Int J Exp Path. 2004 Dec;85(6):345-53. PMID: 15566431 .

34. Al-Azzam SI, Abdul-Razzak KK, Jaradat MW. The nephroprotective effects of pioglitazone and glibenclamide against gentamicininduced nephrotoxicity in rats: a comparative study. J Chemother. 2010 Apr;22(2):88-91. PMID: 20435566.

35. Guedes FS Jr, Cruz DS, Rodrigues MM, Silva LM, Amorim RL, Vianna PT, Castiglia YM. Renal histology and immunohistochemistry after acute hemorrhage in rats under sevoflurane and ketoprofen effect. Acta Cir Bras. 2012 Jan;27(1):37-42. PMID: 22159437.

36. Garrioch MA. The body's response to blood loss. Vox Sang. 2004;87(Suppl 1):74-6. PMID: 15200610.

\section{Correspondence:}

Yara Marcondes Machado Castiglia

Departamento de Anestesiologia

Faculdade de Medicina de Botucatu - UNESP

Caixa Postal 530

18618-970 Botucatu - SP Brasil

yarac@fmb.unesp.br

Received: Mar 21, 2016

Review: May 23, 2016

Accepted: Jun 22, 2016

Conflict of interest: none

Financial source: none

${ }^{1}$ Research performed at Experimental Laboratory of Anesthesiology, Botucatu Medical School, Universidade Estadual Paulista (UNESP), Botucatu-SP, Brazil. Part of Master degree thesis, Postgraduate Program in Anesthesiology, UNESP. Tutor: Yara Marcondes Machado Castiglia. 